\title{
IMPROVING STUDENTS' READING COMPREHENSION OF DESCRIPTIVE TEXT USING CIRC TECHNIQUE
}

\author{
Syamsul Anwar ${ }^{1}$, Ruanda Januar ${ }^{2}$ \\ ${ }^{1}$ IKIP SILIWANGI \\ ${ }^{2}$ IKIP SILIWANGI \\ ${ }^{1}$ anwar_syamsul19@yahoo.co.id, ${ }^{2}$ ruanda007@gmail.com
}

\begin{abstract}
This research become performed in MA Al-Mukhtariyah Mande West Bandung. The objective of this research is used to investigate the implementation of CIRC technique in improving the students reading comprehension of descriptive text. The method used in this research was quantitative method. The design of the research was pre-experimental design. There are three steps involving preexperimental design. The first step is the administration of pre-test measuring the dependent variable. The second step is the application of the experimental treatment (independent variable) to the subjects, and the final step is the administration of a posttest measuring the dependent variable again. It has seven times of conducting data, namely pretest, posttest, and five times treatments. Based on the result of pre-test, we observed that students' reading comprehension is below average, the mean score of pre-test is 42.79 . After the implementation of CIRC technique in every meetings, the students' reading comprehension had been getting better, it is able to be seen in average of the mean score of post-test becam 73.82. It is able to be concluded that CIRC techniqiue can improve students' reading comprehension.
\end{abstract}

Keywords: Reading Comprehension, Descriptive Text, CIRC Technique

\section{INTRODUCTION}

Based on the data from SISDIKNAS 2003, some high school teachers in Indonesia convey that it is rather hard to reach reading comprehension to learners. It is stated that are still confused finding an appropriate method and media to applied in teaching reading comprehension for learners.

Reading is one of the core skills in English that plays significant role. By means of this activity, students can improve their own language and experience. They will get information and ideas which they need to know. Moreover, they will be able to know what they do not know before. As stated by Farris, et. al (Farris, 2004) "Reading comprehension is the process of understanding the message that the author is trying to convey. Very simply, it is making meaning from the text at hand". In other hand, reading comprehension is about guessing or grasping meanings from texts.

In reading, there are many varieties of reading text, consisting of narrative, recount, report, descriptive, explanation, analytical exposition, hortatory exposition, procedure, discussion, news item and so on. In this research, researcher focus on descriptive text as one of genre of text should be taught to students of senior high school.

In teaching reading, they are some problems that can be identified in this research. The problems are lack of vocabularies and background knowledge to understand the text, lack of communication between students and teacher, lack of cooperation between student and other student, and the problem of teachers is the use of method is not appropriate for students in senior high school. Based on the problems, English teachers should find the appropriate method and technique to increase students' interest in reading text to overcome this problem. 
English teachers are expected to find appropriate method and technique to make students understand the text moreover enjoy reading. The technique that can be utilized by the English teacher to enhance the students' reading comprehension or understanding in teaching reading is cooperative learning.

One of cooperative learning method is Cooperative Integrated Reading and Composition (CIRC). "Cooperative integrated reading and Composition (CIRC) is a complete program for teaching reading and writing inside the higher elementary and middle grades" (Stevens, et al. 1987) in (Slavin, 2015). In most CIRC activities, students follow a sequence of teacher instruction, team practice, team pre assessments, and quizzes. That is, students do not take the quiz until their team mates have determined that they are ready. Certificates are given to teams based on the average performance of all team members on all reading and writing activities (Slavin, 2015).

According to Slavin (Slavin, 1995), the students are trained to enchance their ability in reading descriptive text. Steps that the writer use in teaching descriptive text as follows:

1. Teacher explains a subject of English to students, this study used worksheets that contain material that will be taught at each meeting.

2. Teacher gives exercises.

3. Teachers are ready to train students to improve student skills in solving problems through the application of problem-solving model of CIRC.

4. Teachers form groups of heterogeneous students.

5. Teachers prepare about solving the problem in the form of cards and distribute them to each group.

6. Teachers told that in each group there were a series of activities with specific

7. Each group works on the principal activities of the CIRC. Teachers supervise the work of the group.

8. Chairman of the group reported success or barriers.

9. Chairman of the group should be able to establish that each member has to understand, and can do the problem solving the given problem.

10. The teacher asks the class representatives to present findings.

11. Teachers act as resource persons or facilitator.

12. Teacher gives assignment/homework individually.

13. Teachers disperse groups and students return to their seats.

14. Teacher repeats in the classical problem solving strategies on problem solving.

15. Teacher gives quiz.

Based on the ideas above, the researcher takes as a starting point to do a research entitled “IMPROVING STUDENTS' READING COMPREHENSION OF DESCRIPTIVE TEXT USING COOPERATIVE INTEGRATED READING AND COMPOSITION (CIRC) TECHNIQUE".

\section{METHOD}

This research become held in March 2018 at the first grade students in MA Al-Mukhtariyah Mande Cililin, Bandung in the academic year of 2017/2018 with the sample of quantity of the research is one class consist of thirty four students.

The research method can be classified into three broad research categories: (1) Quantitative research method, (2) Qualitative research method, and (3) Mixed methods research designs (Tavakoli, 2012; Creswell, 2009; Lavrakas, 2008; Jupp, 2006) in (Suprijadi \& Kaswan, 2016). 
In this research, the researcher used quantitative research method. It is considered that this research method is appropriate to know the influence of improving the students' reading comprehension using Cooperative Integrated Reading and Composition (CIRC) Technique. Meanwhile, the research design used pre-experimental design are one-group one-shot case study design and one group pretest-posttest design. There are three steps involving preexperimental design. The first step is the administration of pre-test measuring the dependent variable. The second step is the application of the experimental treatment (independent variable) to the subjects, and the final step is the administration of a posttest measuring the dependent variable again.

The researcher used these items as the pretest and posttest which includes three steps. Those are pretest, treatment, and posttest.

1. Pretest

The pretest is administered before the researcher using CIRC technique in teaching reading of descriptive text. It is aimed to know students' knowledge in the reading comprehension of descriptive text.

2. Treatment

The present researcher as a teacher treats the students by applying CIRC technique in teaching reading of descriptive text. Here, the teacher takes a material on the book of $\mathrm{X}$ Class Curriculum 2013 for the treatment. Furthermore, the treatment is conducted five times. The application of CIRC technique is elaborated in the lesson plan.

3. Posttest

Posttest is administered after applying treatment. The posttest items are same with pretest items. Pretest and posttest also have some application when they are conducted in a classroom. Teacher gives a test which consist of 15 multiple choice items to student. The students answer the test in 70 minutes. The purpose of this posttest is to know the students' reading comprehension of descriptive text after using CIRC technique.

After giving the students' test, the researcher used spss 22.0 as tool of calculating and analyzing the result of both pre-test and post-test.

\section{RESULTS AND DISCUSSION}

\section{Results}

The objective of this research is used to investigate whether the implementation of CIRC technique is effective to improve students' reading comprehension of descriptive text at the $\mathrm{X}$ Students of MA Al-Mukhtariyah Mande. Related to the objective, the writer collected data through pre-test and post-test. Beside that, the detail of students' scores can be seen from the following table:

Table 1. The Score of Pre-test and Post-Test

\begin{tabular}{cccc}
\hline \multirow{2}{*}{ NO } & \multirow{2}{*}{ STUDENTS } & \multicolumn{2}{c}{ SCORES } \\
\cline { 3 - 4 } & & PRE-TEST & POST-TEST \\
\hline 1 & STUDENT 1 & 50 & 80 \\
\hline 2 & STUDENT 2 & 30 & 60 \\
\hline 3 & STUDENT 3 & 45 & 75 \\
\hline 4 & STUDENT 4 & 60 & 85 \\
\hline 5 & STUDENT 5 & 60 & 90 \\
\hline 6 & STUDENT 6 & 20 & 60 \\
\hline 7 & STUDENT 7 & 60 & 85 \\
\hline
\end{tabular}


184 Anwar, Januar, Improving Student's Reading Comprehension ...

\begin{tabular}{clll}
\hline 8 & STUDENT 8 & 25 & 60 \\
\hline 9 & STUDENT 9 & 30 & 60 \\
\hline 10 & STUDENT 10 & 45 & 75 \\
\hline 11 & STUDENT 11 & 40 & 70 \\
\hline 12 & STUDENT 12 & 50 & 85 \\
\hline 13 & STUDENT 13 & 40 & 70 \\
\hline 14 & STUDENT 14 & 45 & 75 \\
\hline 15 & STUDENT 15 & 50 & 80 \\
\hline 16 & STUDENT 16 & 60 & 85 \\
\hline 17 & STUDENT 17 & 25 & 60 \\
\hline 18 & STUDENT 18 & 40 & 70 \\
\hline 19 & STUDENT 19 & 50 & 80 \\
\hline 20 & STUDENT 20 & 60 & 85 \\
\hline 21 & STUDENT 21 & 45 & 75 \\
\hline 22 & STUDENT 22 & 10 & 60 \\
\hline 23 & STUDENT 23 & 60 & 90 \\
\hline 24 & STUDENT 24 & 60 & 90 \\
\hline 25 & STUDENT 25 & 25 & 60 \\
\hline 26 & STUDENT 26 & 45 & 75 \\
\hline 27 & STUDENT 27 & 40 & 70 \\
\hline 28 & STUDENT 28 & 40 & 70 \\
\hline 29 & STUDENT 29 & 20 & 60 \\
\hline 30 & STUDENT 30 & 45 & 75 \\
\hline 31 & STUDENT 31 & 40 & 75 \\
\hline 32 & STUDENT 32 & 45 & 90 \\
\hline 33 & STUDENT 33 & 65 & 30 \\
\hline 34 & STUDENT 34 & & \\
\hline & & 30 & 60 \\
\hline
\end{tabular}

By using spss 22.0, the writer analyzed the data based on the pretest and posttest score. The writer gives the report concerning the data description of those two scores.

Table 2. Tests of Normality

\begin{tabular}{|l|r|r|r|r|r|r|}
\hline & \multicolumn{3}{|c|}{ Kolmogorov-Smirnov $^{\mathrm{a}}$} & \multicolumn{3}{c|}{ Shapiro-Wilk } \\
\cline { 2 - 7 } & Statistic & \multicolumn{1}{c|}{$\mathrm{df}$} & \multicolumn{1}{c|}{ Sig. } & Statistic & \multicolumn{1}{c|}{$\mathrm{df}$} & \multicolumn{1}{c|}{ Sig. } \\
\hline pretest & .156 & 34 & .035 & .942 & 34 & .069 \\
posttest & .172 & 34 & .012 & .895 & 34 & .003 \\
\hline
\end{tabular}

a. Lilliefors Significance Correction

As the result of normality test above can be concluded that the score of pretest and posttest had Sig score $<0.05$, for Kolmogorov-Smirnov Normality test that were 0.035 for the pretest and 0.012 for posttest. The Sig score of pretest and posttest less than 0.05 so the test was not finished due to the fact the data was not normal, after which the researcher hold to Nonparametric test.

Non-parametric test or Wilcoxon matched-pairs signed-rank test is used to determine whether the scores from two samples that come from similar cases are significantly different from each other. The differences between pairs of scores are ranked in order of size, ignoring the sign or direction of those differences. The rank of the differences with the same signed are 
added together. If there are no differences between the score of two samples, the sum of positive ranked differences should be similar to the sum of negative ranked difference. The bigger the differences between the positive and negative ranked differences, more likely two sets of scores differ significantly from each other. (Cramer \& Howitt, 2004: 180) in (Suprijadi \& Kaswan, 2013). With the folowing hypothsis:

- If the test is (Asymp $>.05)$ then the differences is non-significant

- If the test is (Asymp. <.05) then the differences is significant

Table 3. The Result of Non-parametric Test

\begin{tabular}{|rl|r|r|r|}
\hline \multicolumn{2}{c|}{ Ranks } \\
\hline posttest - pretest & $\mathrm{N}$ & Mean Rank & Sum of Ranks \\
& Negative Ranks & $0^{\mathrm{a}}$ & .00 & .00 \\
& Positive Ranks & $34^{\mathrm{b}}$ & 17.50 & 595.00 \\
& Ties & $0^{\mathrm{c}}$ & & \\
& 34 & & \\
& Total & & \\
\hline
\end{tabular}
a. posttest < pretest
b. posttest $>$ pretest
c. posttest $=$ pretest

Table 4.

Test Statistics $^{\mathrm{a}}$

\begin{tabular}{|l|r|}
\hline & \multicolumn{2}{|c|}{ posttest - pretest } \\
\hline$Z$ & $-5.262^{\mathrm{b}}$ \\
Asymp. Sig. (2-tailed) & .000 \\
\hline
\end{tabular}
a. Wilcoxon Signed Ranks Test
b. Based on negative ranks.

According to the table above, the mean rank is 17.50 , sum of rank is 595.00 and $Z=-5.262$. If the test is non-significant (Asymp > .05) and significant if (Asymp. <.05). We are able to see the Asymp. Sig. (2-tailed) value is less than 0.05. It means the differences between pretest and posttest score are significant. Beside that, the researcher used descriptive statistic on SPSS to know the mean and standard deviation.

Table 4.5

\section{The Result of Descriptive Statistics}

\begin{tabular}{|l|r|r|r|r|r|}
\hline & $\mathrm{N}$ & \multicolumn{1}{|c|}{ Descriptive Statistics } \\
\hline pretest & 34 & 42.79 & Std. Deviation & Minimum & Maximum \\
posttest & 34 & 73.82 & 13.937 & 10 & 65 \\
\hline
\end{tabular}

Based on the table above we are able to see the improvement statistic of data pretest and posttest, mean of pretest is 42.79 and the mean of posttest is 73.82 . and standard deviation has decreased it means the data is representative.

\section{Discussion}

This section explain the discussion of improving reading comprehension through CIRC technique. The finding research showed that CIRC technique can improve students' reading 
comprehension. It is able to be seen from the improvement of the students' score. The students' mean score of pretest was 42.79. After the implementation of CIRC technique, the mean scores of posttest became 73.82 and it supported by the Asymp. Sig. (2-tailed) value is less than 0.05 . The differences between pretest and posttest score are significant. It suggest the result of this study confirm the previous studies that the application of CIRC technique improved the students' reading comprehension. Beside that, the implementation of CIRC technique were given positive responses from students in their teaching learning process of reading comprehension.

\section{CONCLUSION}

The researcher became performed through pre-experimental design which is aimed to discover whether CIRC technique is effective to improve students' reading comprehension or not. As the statistical calculation above, there is a significant difference in implementation of CIRC technique to improve the students' reading comprehension at the X students of MA AlMukhtariyah Mande.

Based on the result at the previous table, the result of the students' reading comprehension test increased from the pretest to posttest score. The average of the pretest is 42.79 and the posttest is 73.82. There are a significant differences between pretest and posttest score. it is able to be concluded that the alternative hypothesis of this technique was normal, it means that the CIRC technique is effective and significantly improve the students' reading comprehension.

\section{ACKNOWLEDGMENTS}

Alhamdulillahirabbil'alamin, all praises be to Allah Ta'ala who has given the writer health and strength to accomplish this journal. Thanks to IKIP Siliwangi especially English Education Study Program. And also MA Al-Mukhtariyah Mande as the place of the research. I would like to thank to Dr. Odo Fadloeli, M.Pd as the supervisor, for his advices in the improvement of the result of this journal.

Finally, I hope this journal will have some contributions and be useful no matter how small and imperfect it is. The suggestion and critics are welcomed.

\section{REFERENCES}

Farris, P. J. (2004). Teaching Reading: A Balanced Approach For Today's Classrooms. New York: McGraw Hill.

Slavin, R. E. (1995). Cooperative Learning theory, Research and Practice Socond Edition. Boston: A Simon and Schuster Company.

Slavin, R. E. (2015). Cooperative Learning in Schools. International Encyclopedia of Social \& Behavioral Sciences (Second Edition, Vol. 4). Elsevier. http://doi.org/10.1016/B9780-08-097086-8.92028-2

Suprijadi, D., \& Kaswan. (2013). Research in English Language Education. Bandung: STKIP Siliwangi Bandung.

Suprijadi, D., \& Kaswan. (2016). Research in English Language Education. Bandung: STKIP Siliwangi Bandung. 